\title{
STUDI KOMPARASI INFOGRAFIS PENCEGAHAN VIRUS CORONA
}

\author{
Wisnu Wijaya \\ Desain Komunikasi Visual, Program Studi Magister Penciptaan dan Pengkajian Seni \\ Fakultas Seni Rupa, Pascasarjana ISI Yogyakarta \\ Jalan Suryodiningratan No. 8, Yogyakarta, Indonesia \\ e-mail : wisya.design@gmail.com \\ Diterima : 16 Maret 2020. Disetujui : 8 April 2020. Dipublikasikan : 10 Juni 2020 \\ (O2020 - DESKOVI Universitas Maarif Hasyim Latif. Ini adalah artikel dengan akses \\ terbuka di bawah lisensi CC BY 4.0 (https://creativecommons.org/licenses/by/4.0/)
}

\begin{abstract}
ABSTRAK
Infografis digunakan oleh media massa untuk menyampaikan informasi dan kontrol sosial terkait fenomena yang sedang terjadi termasuk persebaran virus Corona yang semakin meluas ke Indonesia sejak Maret 2020. Tujuan penelitian ini adalah untuk mengetahui tingkat penerapan prinsip desain analitik dalam infografis pencegahan virus Corona, serta untuk mengetahui makna dari tanda-tanda di dalamnya. Sampel infografis dikumpulkan dari lima media berita online di Indonesia yang dipublikasikan dari bulan Januari hingga April 2020 dalam batasan konteks pencegahan virus Corona. Prosedur penelitian dibagi menjadi dua kelompok. Pertama, metode komparatif kuantitatif melalui penyebaran angket dengan modifikasi System Usability Scale (SUS) untuk mengetahui efektivitas penerapan prinsip-prinsip desain analitik dari Edward Tufte. Kedua, metode kualitatif deskriptif melalui pendekatan semiotika dari Peirce untuk mengungkap makna tanda visual dan verbal. Hasil penilitian menyatakan bahwa kelima infografis tersebut sudah memperhatikan prinsip desain analitik seperti hubungan sebab-akibat, persuasi, keterbacaan, dan komprehensif, serta sebagian besar menggunakan pendekatan naratif eksploratif sebagai struktur penyampaian informasi.
\end{abstract}

Kata kunci: virus Corona, infografis, prinsip desain analitik Tufte, semiotika Peirce

\begin{abstract}
Infographics is used by the mass media to convey information and social control related to the phenomenon that is happening, including Corona virus which has increasingly spread to Indonesia since March 2020. The purpose of this study was to determine the level of application of infographic analytic design principles related to Corona virus prevention, as well as to find out the meaning of the signs inside. The infographic sample was collected from five online news media in Indonesia, which were published from January to April 2020 within the context of the Corona virus prevention context. The research procedure was divided into two groups. First, quantitative comparative methods through questionnaires using the modification of System Usability Scale (SUS) analysis to determine the effectiveness of applying analytic design principles of Edward Tufte. Second, the descriptive qualitative method through Peirce's semiotics approach to reveal the meaning of visual and verbal signs. The research stated that the seven infographics had paid attention to analytic design principles such as causability, persuasion, legibility, and comprehensive, also used explorative narrative approaches as a structure for information delivery.
\end{abstract}

Keyword: Corona virus, infographics, Tufte's principles of analytic design, Peirce's semiotics

\section{PENDAHULUAN}

Infografis merupakan kependekan dari informasi grafis. Perkembangan infografis dalam ranah digital mulai meningkat sejak 2010 dan berlanjut hingga sekarang. Dalam ranah digital, infografis memiliki kelebihan dapat disebarkan melalui media sosial secara cepat. Kecenderungan pembaca di dunia maya atau netizen adalah ingin menemukan informasi dan bisa memahaminya secara cepat. Kecenderungan tersebut dapat diatasi oleh infografis. Infografis online digunakan oleh media massa untuk menyampaikan informasi dan kontrol sosial terkait fenomena yang sedang terjadi karena beberapa kelebihan yang tidak dimiliki oleh format lain. Fenomena hangat terkini adalah persebaran Covid-19 secara global yang disebabkan oleh virus Corona. Covid-19 merupakan label untuk nama penyakitnya, sedangkan Corona adalah label untuk nama virusnya. Covid-19 adalah penyakit menular di mana sebagian besar orang yang terinfeksi akan mengalami penyakit pernapasan ringan hingga sedang. Orang yang lebih tua dan orang yang 
memiliki masalah medis seperti penyakit kardiovaskular, diabetes, penyakit pernapasan kronis, dan kanker kemungkinan akan menderita penyakit lebih serius (WHO, 2020).

Kasus pertama Covid-19 di Indonesia dinyatakan oleh Kementrian Kesehatan pada tanggal 1 Maret 2020 dengan dua warga Depok positif terjangkit virus Corona. Penyebaran Covid-19 pun semakin meluas ke seantero Indonesia. Presiden Indonesia, Joko Widodo, dalam sebuah kesempatan menyampaikan bahwa sudah waktunya orang bekerja dari rumah dan sekolah diliburkan (Liputan6.com, 2020). Dengan demikian, media massa online pun berperan penting dalam menyampaikan informasi terkait Covid-19 terutama pada masa orang bekerja dari rumah (work from home) dan masa sekolah diliburkan. Media massa berperan aktif membantu pemerintah dalam memberitakan informasi terkait Covid-19 yang secara etik lebih mengedepankan informasi yang perlu diketahui publik, misalnya mengenai upaya pencegahan virus Corona.

Tujuan dari penelitian ini adalah untuk mengetahui tingkat penerapan prinsip desain analitik pada infografis terkait tema pencegahan virus Corona serta untuk mengetahui makna dari tanda-tanda (visual dan verbal) dalam infografis yang diproduksi oleh media massa online di Indonesia. Selanjutnya, penelitian ini diharapkan dapat bermanfaat secara teoretis sebagai gambaran prinsip-prinsip apa saja yang seharusnya diperhatikan dalam infografis supaya pembaca mendapatkan informasi dengan tingkat miskomunikasi rendah serta sebagai gambaran sistem produksi tanda baik visual dan verbal sampai menghasilkan makna.

Manfaat praktis penelitian ini adalah untuk menjadi sarana tolak ukur dalam meningkatkan kualitas infografis terutama di media sosial. Data infografis yang diteliti dalam penelitian ini dikumpulkan dari lima media berita online di Indonesia yang dipublikasikan dari bulan Januari hingga April 2020 dalam konteks tema mengenai pencegahan virus Corona untuk masyarakat Indonesia. Infografis sampel penelitian ini dikumpulkan dari situs CNN Indonesia.com, Kompas.com, Kumparan.com, Indonesiabaik.id, dan Katadata.co.id.

Prosedur penelitian dibagi menjadi dua kelompok besar. Pertama, metode komparatif kuantitatif melalui penyebaran angket usability testing dengan modifikasi System Usability Scale (SUS) untuk mengetahui efektivitas penerapan prinsip-prinsip infografis. Kedua, metode kualitatif deskriptif dengan pendekatan semiotika Peirce untuk mengungkap makna tanda visual dan verbal dalam infografis. Peneliti menentukan rumusan masalah sebagai berikut: Apa saja persamaan dan perbedaan terkait penerapan prinsip desain analitik infografis dan makna tandatanda dalam infografis dengan tema pencegahan virus Corona yang diproduksi oleh media massa online di Indonesia?

\section{Infografis}

Infografis merupakan kependekan dari informasi grafis, salah satu ruang lingkup dari ilmu desain komunikasi visual. Format infografis yang menjadi sampel dalam perancangan ini berformat statis. Format ini umum digunakan di media online di Indonesia dengan pertimbangan lebih cepat untuk diproduksi dibandingkan format interaktif dan animasi. Selain itu, infografis format statis dapat ditampilkan di website maupun media cetak. Penerapan infografis statis dengan format vertikal dalam konten editorial marak digunakan seiring banyaknya publikasi infografis dalam blog, website dan Instagram.

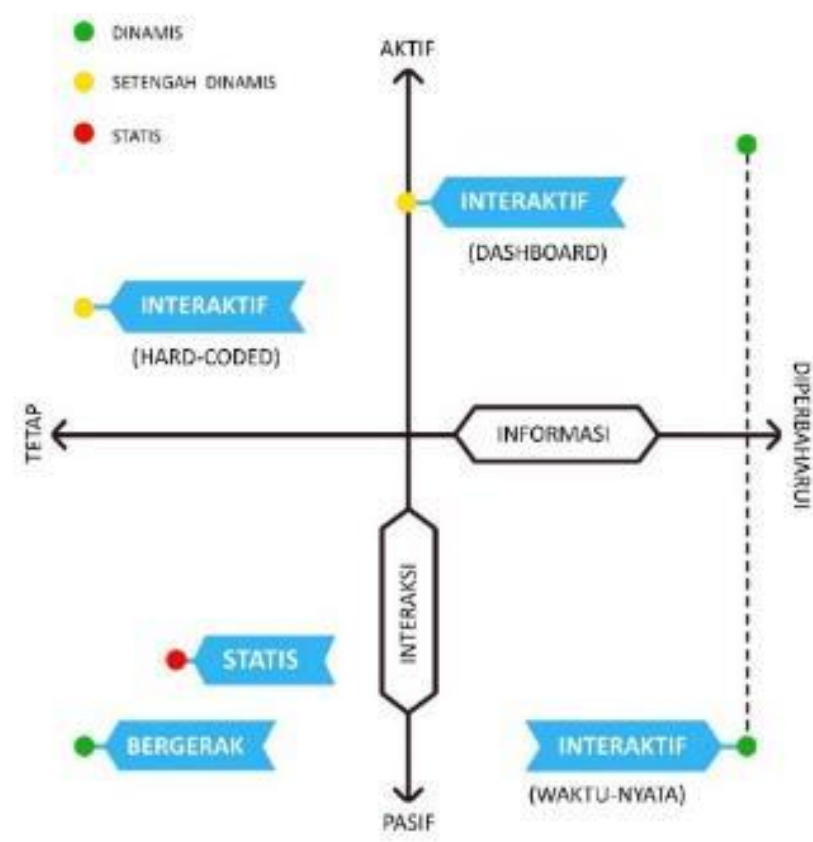

Gambar 1. Kuadran Format Infografik Sumber: buku Infografik - Kedahsyatan Cara Bercerita Visual, Jason Lankow

Gambar di atas menunjukkan posisi infografis format statis di bagian kiri bawah. Karakternya cenderung kurang interaktif dan pembaca menjadi konsumen tanda yang secara pasif mencerna informasi. Salah satu kelemahan format statis adalah bahwa informasi itu bisa ketinggalan dalam konteks waktu dalam menyajikan laporan tertentu. Sehingga, produsen perlu membuat lagi infografis format statis yang diperbaharui secara teratur untuk menampilkan informasi terkini (Jason Lankow, 2014:60).

Proses penelitian secara kuantitatif dalam penelitian ini menggunakan System Usability Scale (SUS) untuk mengetahui efektivitas penerapan prinsipprinsip desain analitik infografis. Pertanyaan yang disusun dalam angket tersebut mengandung kriteria yang sejalan dengan pendekatan prinsip desain analitik dari Edward Tufte. System Usability Scale (SUS) merupakan metode survey yang didesain oleh John Brooke pada tahun 1986. Metode tersebut menggunakan sepuluh pertanyaan dengan jawaban responden dalam lima skala. Nilai 1 berarti sangat tidak setuju, 2 berarti tidak setuju, 3 berarti netral, 4 berarti 
setuju, sedangkan 5 berarti sangat setuju. Cara ini meliputi beberapa aspek penilaian seperti unsur kegunaan, pembelajaran, konsistensi, pelatihan, integritas, dan kompleksitas (Chauncey Wilson, 2013:82). Pada dasarnya SUS digunakan untuk menguji aplikasi perangkat lunak. Namun, peneliti memodifikasi melalui penyesuaian pertanyaan yang diselaraskan dengan prinsip desain analitik dari Edward Tufte untuk kebutuhan infografis.

\begin{tabular}{|c|c|c|c|c|}
\hline $\begin{array}{c}\text { Strongly } \\
\text { Disagree } \\
\mathbf{1}\end{array}$ & $\mathbf{2}$ & $\mathbf{3}$ & $\mathbf{4}$ & $\begin{array}{c}\text { Strongly } \\
\text { Agree } \\
\mathbf{5}\end{array}$ \\
\hline 0 & 0 & 0 & 0 & 0 \\
\hline
\end{tabular}

Gambar 2. Skala penilaian SUS

Sumber: https://medium.com/kelasux/bagaimanamengukur-kebergunaan-produk-dengan-system-usabilityscale-sus-score-2d6843ca780a

Proses meninjau dan memaknai karya infografis secara kualitatif dalam penelitian ini menggunakan pendekatan semiotika yang diusung oleh Charles Sander Peirce. Gagasan semiotika dari Peirce disebut sebagai grand theory dalam semiotika karena bersifat menyeluruh, deskripsi struktural dari semua sistem penandaan (Sobur, 2001:97). Upaya yang dilakukan Peirce antara lain membagi jenis tanda menjadi ikon, indeks dan simbol berdasarkan relasi di antara penanda dan objeknya. Identifikasi tanda dalam infografis dengan tema pencegahan virus Corona dilakukan menggunakan tiga jenis tanda tersebut dengan penjelasan sebagai berikut:

1. Ikon, yaitu tanda yang mempunyai hubungan keserupaan dengan objek rujukannya.

2. Indeks, yaitu tanda yang mempunyai hubungan sebab-akibat dengan objek rujukannya.

3. Simbol, yaitu tanda yang mempunyai hubungan arbiter atau artifisial dengan objeknya atau bersifat konvensional (Piliang, 2012:350).

Tahapan peninjauan karya infografis dengan pendekatan semiotika merujuk pada proses yang ditawarkan oleh Feldman dan Garret. Unsur pertama dalam meninjau karya adalah deskripsi, yaitu menyebutkan, mencatat dan melaporkan apa yang dilihat oleh pembaca secara wujud. Unsur kedua adalah menganalisis, yaitu menyatakan bagaimana suatu karya tersusun beserta keterangan sifat, kualitas dan elemen seni rupa pembentuknya. Unsur ketiga adalah interpretasi, yaitu mengutarakan makna suatu karya seni. Unsur terakhir adalah menyatakan nilai atau mutu suatu karya seni (Nooryan Bahari, 2017:111).

Penggunaan metode kualitatif dan kuantitaif di atas membantu peneliti membandingkan persamaan dan perbedaan sampel infografis untuk mengetahui bagaimana penyampaian pesan melalui tanda verbal dan visual dapat dipahami oleh pembaca berdasarkan kerangka pemikiran yang telah ditentukan. Peneliti menggunakan metode kuantitatif dan kualitatif dengan pertimbangan bahwa infografis statis merupakan perpaduan antara wilayah desain grafis dan analisis data seperti digambarkan pada diagram venn di bawah. Infografis menjadi kolaborasi antara pemecahan masalah, alur kerja, penyajian solusi secara visual, dan penyampaian kritik.

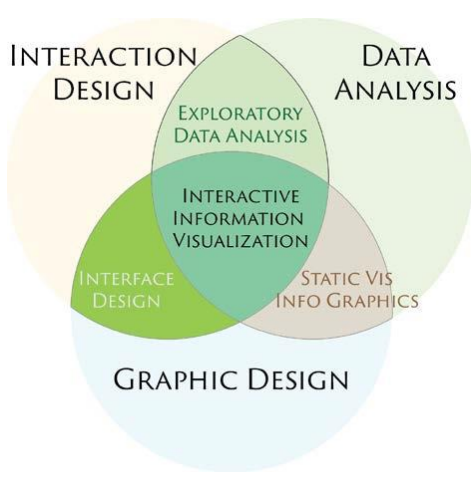

Gambar 3. diagram venn area kerja infografis sumber: Gerald Benoît, 2019:14

\section{Prinsip dasar desain analitik Tufte}

Prinsip dasar desain analitik (fundamental principles of analytical design) antara lain sebagai berikut (Tufte, 2006:124-136):

1. Comparison yaitu menunjukkan perbandingan, kontras, dan perbedaan.

2. Causality, mechanism, structure, explanation yaitu memperlihatkan hubungan sebab-akibat, mekanisme, struktur sistematis, dan penjelasan.

3. Multivariate Analysis yaitu menampilkan data multivarian, yaitu terdiri lebih 2 variabel.

4. Sepenuhnya mengintegrasikan kata, angka, gambar, dan diagram.

5. Integritas dan kredibilitas, menjelaskan bukti menyeluruh. Unsur di dalamnya antara lain: judul yang terperinci, menunjukkan penulis, sumber data, skala pengukuran, dan masalah yang relevan.

6. Presentasi analitik pada akhirnya berdiri tergantung pada kualitas, relevansi, dan integritas konten mereka.

\section{Kerangka Berpikir}

Pernyataan kerangka berpikir dalam penelitian ini adalah bahwa suatu infografis dapat dianggap efektif apabila unsur tanda baik visual maupun verbal dapat dipahami dan mempersuasi pembaca serta mampu membantu pembaca dalam berpikir secara logis. Infografis sepatutnya tidak hanya menampilkan elemen visual yang artistik saja, namun mampu bekerja sama dengan tanda verbal serta sistematika yang mampu dicerna oleh pembaca.

\section{METODE PENELITIAN}

Peneliti menggunakan metode kuantitatif dan kualitatif dengan pertimbangan bahwa infografis membutuhkan dua pendekatan dalam mengungkap nilai-nilai yang di dalamnya karena infografis itu sendiri merupakan perpaduan antara wilayah desain 
grafis dan analisis data. Variabel bebas atau variabel yang mempengaruhi dalam penelitian ini adalah cara pencegahan virus Corona, sedangkan variabel terikat atau variabel yang dipengaruhi adalah tingkat efektifitas tanda verbal dan visual dalam infografis. Sampel penelitian menggunakan lima infografis dari media online di Indonesia.

Instrumen penelitian atau secara umum disebut alat bantu pengumpulan data dalam penelitian ini berupa dokumentasi dari media online terkait. Sebagai tambahan catatan, peneliti menyebut sumber data yang dimaksud dalam infografis adalah sebagai sumber primer (peneliti, badan kesehatan resmi, pemerintah, dan sebagainya).

Teknik pengumpulan data lainnya adalah studi literatur dengan mengumpulkan sumber tertulis yang berhubungan dengan ilmu semiotika, infografis dan analitik desain.

\section{Metode Komparatif Kuantitatif}

Penelitian menggunakan analisis System Usability Scale (SUS) bertujuan untuk mengetahui tingkat penerapan prinsip desain analitik dalam infografis. Tahap ini dimulai dengan menyiapkan sepuluh pertanyaan, kemudian responden menjawab pertanyaan tersebut berdasarkan seberapa banyak mereka setuju terhadap infografis yang dicermati dalam skala $1-5$. Nilai 1 berarti sangat tidak setuju, nilai 2 berarti tidak setuju, nilai 3 berarti netral, nilai 4 berarti setuju, sedangkan nilai 5 berarti sangat setuju.

Pertanyaan dibagi menjadi dua kategori, yaitu pertanyaan bernada positif dan negatif. Pertanyaan bernada positif diletakkan pada nomer 1, 3, 5, 7, dan 9 . Pertanyaan bernada negatif diletakkan pada nomer 2, 4, 6, 8, dan 10. Sepuluh pertanyaan System Usability Scale (SUS) untuk infografis dengan tema pencegahan virus Corona pada tabel di bawah ini secara tersirat telah berisi prinsip-prinsip desain analitik Edward Tufte, antara lain.

\begin{tabular}{|l|l|c|c|}
\hline No & \multicolumn{1}{|c|}{ Pertanyaan } & Kesan & Prinsip \\
\hline 1 & $\begin{array}{l}\text { Saya pikir infografis ini } \\
\text { mudah dipahami karena } \\
\text { ada hubungan antara } \\
\text { gejala klinis penderita } \\
\text { virus Corona dengan } \\
\text { cara pencegahan. }\end{array}$ & $(+)$ & causality \\
\hline 2 & $\begin{array}{l}\text { Saya merasa infografis } \\
\text { ini datanya kurang } \\
\text { variatif karena secara } \\
\text { umum saya tahu } \\
\text { pencegahan yang } \\
\text { disampaikannya. }\end{array}$ & $(-)$ & $\begin{array}{l}\text { Multi- } \\
\text { variate } \\
\text { analysis }\end{array}$ \\
\hline 3 & $\begin{array}{l}\text { Saya pikir infografis ini } \\
\text { mengandung kesesuaian } \\
\text { dan integrasi antara data } \\
\text { verbal, angka, gambar, } \\
\text { dan diagram. }\end{array}$ & $(+)$ & integrity \\
\hline
\end{tabular}

\begin{tabular}{|c|c|c|c|}
\hline 4 & $\begin{array}{l}\text { Saya merasa infografis } \\
\text { ini kurang persuasif, } \\
\text { kurang mengajak } \\
\text { pembaca tergerak untuk } \\
\text { mencegah penyebaran } \\
\text { virus Corona. }\end{array}$ & $(-)$ & persuasive \\
\hline 5 & $\begin{array}{l}\text { Saya pikir ada } \\
\text { pengetahuan baru } \\
\text { melalui cara } \\
\text { perbandingan atau } \\
\text { perbedaan terkait virus } \\
\text { Corona. }\end{array}$ & $(+)$ & comparison \\
\hline 6 & $\begin{array}{l}\text { Saya merasa teks dalam } \\
\text { infografis ini sulit } \\
\text { dibaca karena pemilihan } \\
\text { font kurang tepat, warna } \\
\text { kurang kontras atau } \\
\text { terlalu banyak teks. }\end{array}$ & $(-)$ & readibility \\
\hline 7 & $\begin{array}{l}\text { Saya rasa mayoritas } \\
\text { pembaca dapat } \\
\text { mempelajari tips } \\
\text { pencegahan yang } \\
\text { disampaikan dengan } \\
\text { cepat. }\end{array}$ & $(+)$ & $\begin{array}{l}\text { Compre- } \\
\text { hensive }\end{array}$ \\
\hline 8 & $\begin{array}{l}\text { Saya merasa infografis } \\
\text { ini kurang menarik } \\
\text { perhatian secara visual, } \\
\text { baik dari pemilihan } \\
\text { warna, tata letak dan } \\
\text { ilustrasi. }\end{array}$ & $(-)$ & $\begin{array}{c}\text { interest/ } \\
\text { attractivity }\end{array}$ \\
\hline 9 & $\begin{array}{l}\text { Saya yakin terhadap } \\
\text { infografis pencegahan } \\
\text { virus karena ada bukti } \\
\text { data yang relevan } \\
\text { dengan kondisi saat ini. }\end{array}$ & $(+)$ & evidency \\
\hline 10 & $\begin{array}{l}\text { Saya merasa tingkat } \\
\text { kredibilitas infografis } \\
\text { ini rendah karena } \\
\text { penyantuman sumber } \\
\text { data kurang jelas, tidak } \\
\text { spesifik atau tidak } \\
\text { terlihat. }\end{array}$ & $(-)$ & credibility \\
\hline
\end{tabular}

Nilai jawaban untuk pertanyaan nomer 1,3,5,7 dan 9 didapatkan dari skala penilaian dikurangi 1 (x-1), sedangkan pertanyaan untuk nomer $2,4,6,8$, da 10 nilai didapat dari 5 dikurang skala penilaian $(5-x)$. Hasil penjumlahan dari nilai score dikalikan dengan angka 2.5 untuk mendapatkan nilai SUS (John Brooke, 1996:189). Setelah pengumpulan data responden, data tersebut dihitung menggunakan beberapa aturan skor System Usability Scale atau SUS (Chauncey Wilson, 2013:84) antara lain sebagai berikut: 
1. Skor dari pertanyaan bernomor ganjil akan dikurangi 1.

2. Skor dari pertanyaan bernomor genap adalah selisih skor responden dengan angka 5 .

3. Skor akhir SUS responden didapatkan dari penjumlahan semua skor pertanyaan 1 sampai 10, kemudian dikali 2,5.

Perhitungan selanjutnya adalah untuk mengetahui skor SUS rata-rata dari semua responden yang dicari melalui penjumlahan semua skor, kemudian dibagi dengan jumlah responden. Skor SUS terakhir tersebut dapat ditarik menjadi interpretasi nilai dengan pedoman sebagai berikut:

\begin{tabular}{|c|c|c|}
\hline SUS Score & Grade & Adjective Rating \\
\hline$>80.3$ & A & Excellent \\
\hline $68-80.3$ & B & Good \\
\hline 68 & C & Okay \\
\hline $51-68$ & D & Poor \\
\hline$<51$ & F & Awful \\
\hline
\end{tabular}

Gambar 4. Pedoman nilai rata-rata sus Sumber: https://medium.com/kelasux/ bagaimana-mengukur-kebergunaanproduk-dengan-system-usability-scalesus-score-2d6843ca780a

\section{Metode kualitatif deskriptif}

Pengolahan data dari sampel berupa karya infografis dalam penelitian ini menggunakan metode kualitatif deskriptif dengan pendekatan semiotika Peirce. Konsep semiotika yang ditawarkan Peirce adalah dengan membagi jenis tanda menjadi ikon, indeks dan simbol berdasarkan relasi di antara penanda dan objeknya. Langkah analisis dalam penelitian ini terdiri dari:

1. Tahap penyuntingan atau pemetaan data.

2. Tahap pengelompokan dan interpretasi tanda dalam jenis ikon, indeks dan simbol.

Peneliti menggunakan pendekatan semiotika dari Charles Sander Peirce pada tahap interpretasi tanda. Semiotika digunakan pada tahap interpretasi karena mampu memfokuskan perhatiannya terutama pada teks di mana penerima atau pembaca dipandang memainkan peran aktif yang dipengaruhi oleh budaya setempat (John Fiske, 2002:40). Peneliti menentukan instrumen penelitian berupa unit-unit yang dianalisis ke dalam tiga jenis tanda menggunakan pendekatan semiotika Peirce seperti dalam tabel berikut:

\begin{tabular}{|c|c|}
\hline Jenis & Unit Analisis \\
Tanda & \\
\hline
\end{tabular}

\begin{tabular}{|c|l|}
\hline Ikon & $\begin{array}{l}\text { Ilustrasi yang mempunyai kemiripan } \\
\text { dengan objek aslinya baik dengan teknik } \\
\text { vektor, teknik tiga dimensi atau gambar } \\
\text { tangan. }\end{array}$ \\
\hline Indeks & $\begin{array}{l}\text { Warna yang mendominasi, warna latar } \\
\text { belakang, garis atau bentuk yang } \\
\text { bermakna tertentu dengan hubungan } \\
\text { sebab-akibat dengan objek, pakaian yang } \\
\text { digunakan karakter tertentu. }\end{array}$ \\
\hline Simbol & $\begin{array}{l}\text { Logo, isyarat dan bahasa tubuh pada } \\
\text { karakter, teks slogan, teks headline, teks } \\
\text { subheadline, teks bodycopy, tipografi, } \\
\text { pemilihan jenis font. }\end{array}$ \\
\hline
\end{tabular}

Tabel 2. Unit analisis penentuan jenis tanda

\section{HASIL DAN PEMBAHASAN}

\section{Perbandingan skor SUS}

Hasil survei berikut didapatkan dari 20 orang responden dalam rentang usia 16 - 40 tahun dengan profesi sebagai pelajar, mahasiswa, graphic designer, guru, dan wiraswasta. Hasil skor SUS infografis pencegahan virus Corona pada gambar grafik di bawah ini antara lain: infografis CNNIndonesia.com berada dalam grade $\mathrm{B}$ dengan kata lain masuk dalam rating Good. Infografis lainnya seperti Kompas.com, Kumparan, Indonesiabaik.id, dan Katadata.co.id masuk dalam grade $\mathrm{A}$, dengan kata lain masuk dalam rating Excellent. Skor SUS Final tertinggi dipegang oleh Indonesiabaik.id sebanyak 84,8 poin.

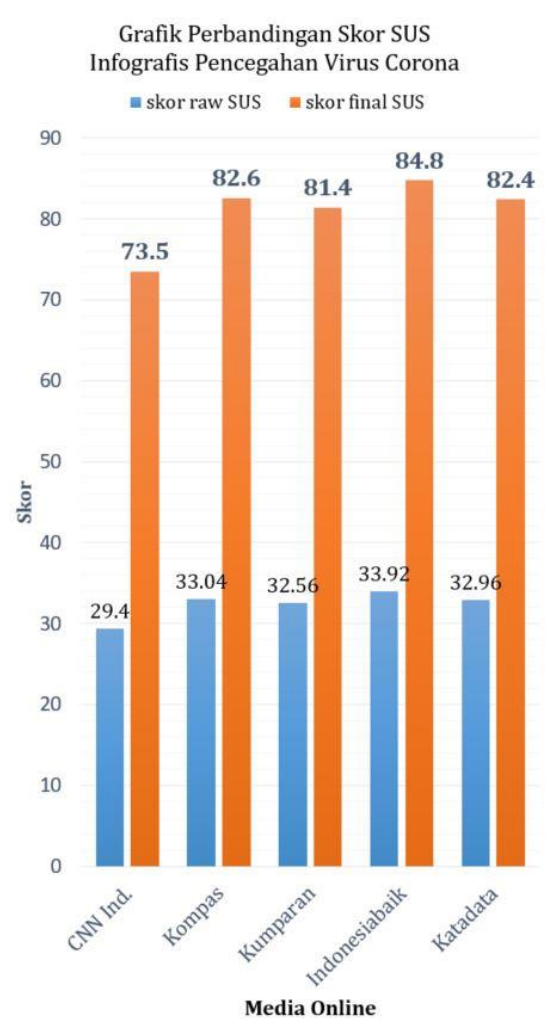

Gambar 5. Grafik perbandingan skor sus infografis pencegahan virus corona pada media online Indonesia sumber: dokumentasi peneliti 
Peneliti memilah lebih rinci hasil SUS ke dalam beberapa kategori yang telah ditentukan sebelumnya pada tabel 1 berisi pertanyaan SUS terkait infografis pencegahan virus Corona. Pertanyaan tersebut secara tersirat memiliki kandungan beberapa prinsip penting dalam infografis, terutama prinsip desain analitik yang disampaikan oleh Edward Tufte. Prinsip-prinsip dalam infografis yang dijadikan parameter penilaian dalam penelitian ini adalah: causality (kausalitas), multivariate analysis (analisis multivarian), integrity (integritas), persuasive (persuasif), comparison (perbandingan), readability (keterbacaan), comprehensive (komprehensif), interest (menarik minat), evidency (bukti/ evidensi), dan credibility (kredibilitas).

Berikut grafik perbandingan skor SUS berdasarkan prinsip desain analitik pada infografis:

Grafik Penerapan

Prinsip Desain Analitik Dalam Infografis

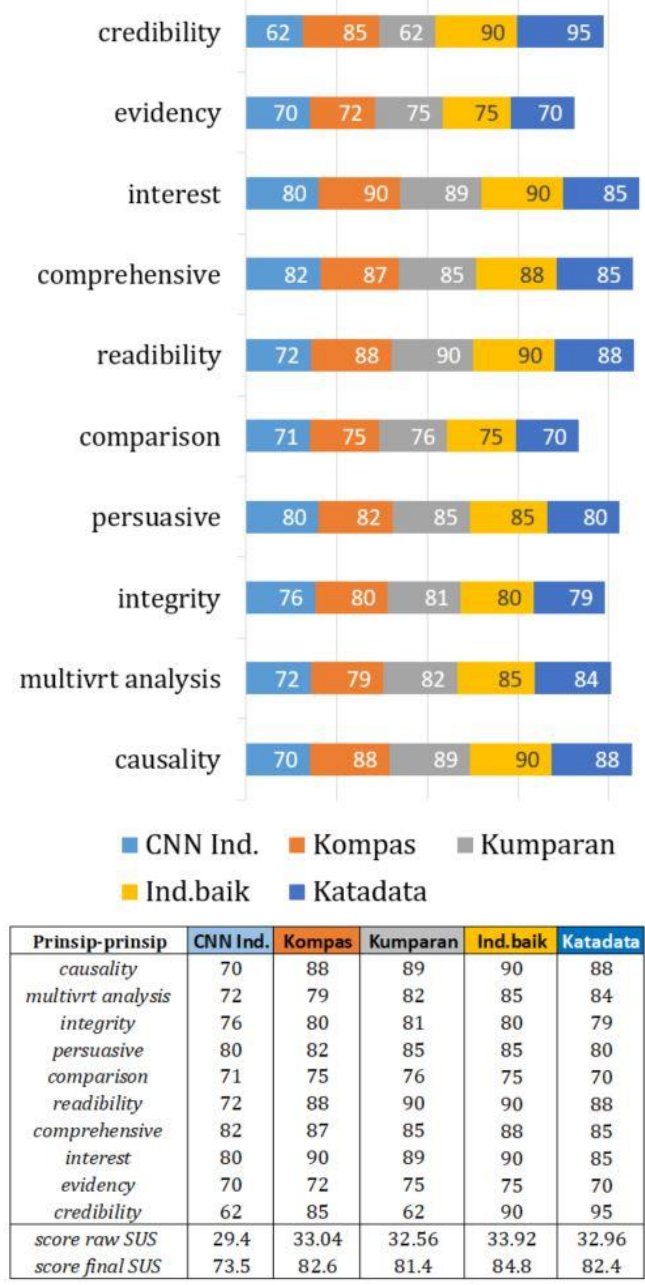

Gambar 6. Grafik perbandingan skor

berdasarkan prinsip-prinsip desain analitik dalam infografis

sumber: dokumentasi peneliti

Kelima infografis tersebut memperhatikan prinsip hubungan sebab-akibat (causality), persuasi, keterbacaan, dan komprehensif. Dua dari lima infografis, yaitu CNNIndonesia.com dan Kumparan.com kurang memperhatikan kredibilitas dengan tidak menyantumkan teks sumber data primer secara spesifik.

\section{Kajian pertama: infografis dari CNN Indonesia}

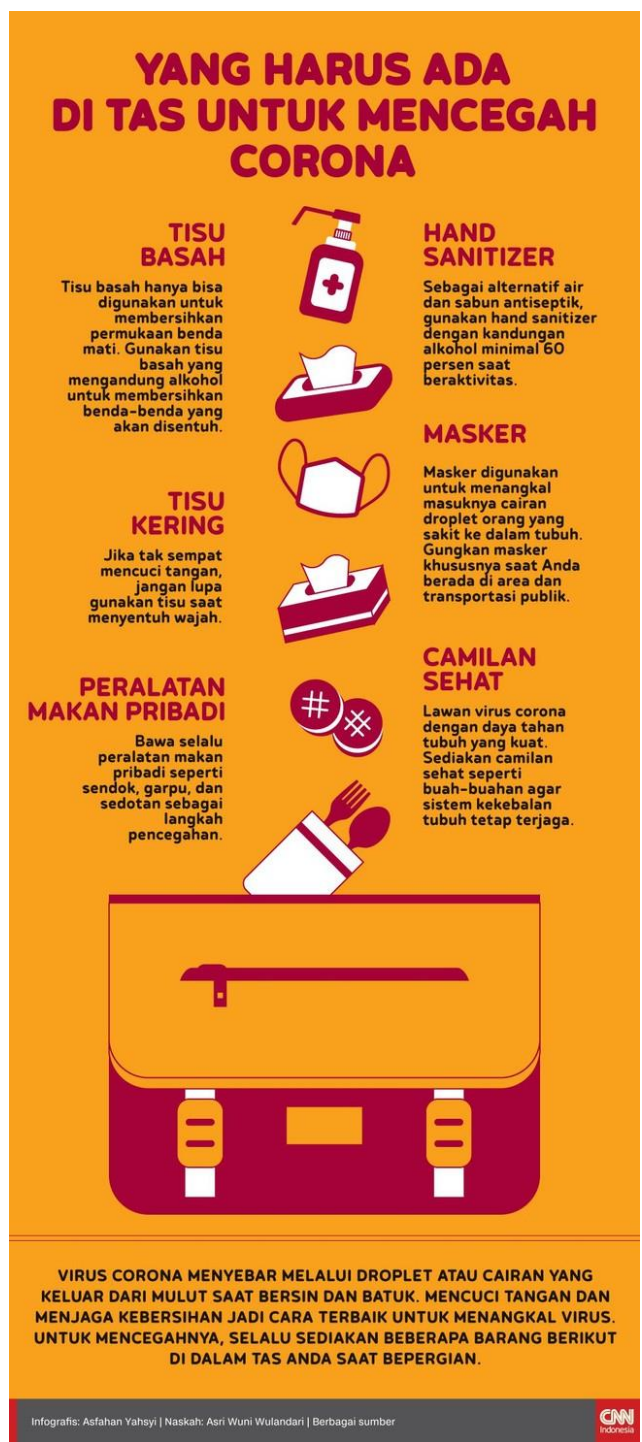

Gambar 7. infografis CNN Indonesia

"Yang harus ada di tas untuk mencegah Corona" Sumber: https://www.cnnindonesia.com/ gaya-hidup/20200303143357-258-480097/

infografis-yang-harus-ada-di-tas-untuk-cegah-corona Diakses pada 5 Maret 2020

\section{Ikon infografis CNN Indonesia}

Ikon hand sanitizer, tisu basah, masker, tisu kering, camilan, dan peralatan makan diilustrasikan dengan teknik vector. Ikon yang menarik fokus perhatian karena memiliki skala terbesar adalah ikon tas model jinjing selempang atau sling bag ukuran besar yang biasa digunakan sebagai tas untuk kebutuhan sekolah, ke kampus dan bekerja. Ikon tas diposisikan di bagian bawah supaya pembaca melihat terlebih dahulu ikon-ikon benda yang menjadi point penting dalam infografis ini. 
Gambar di bawah ini merupakan layout penyederhanaan untuk memetakan tanda verbal dan visual yang ada pada infografis dari situs tersebut.

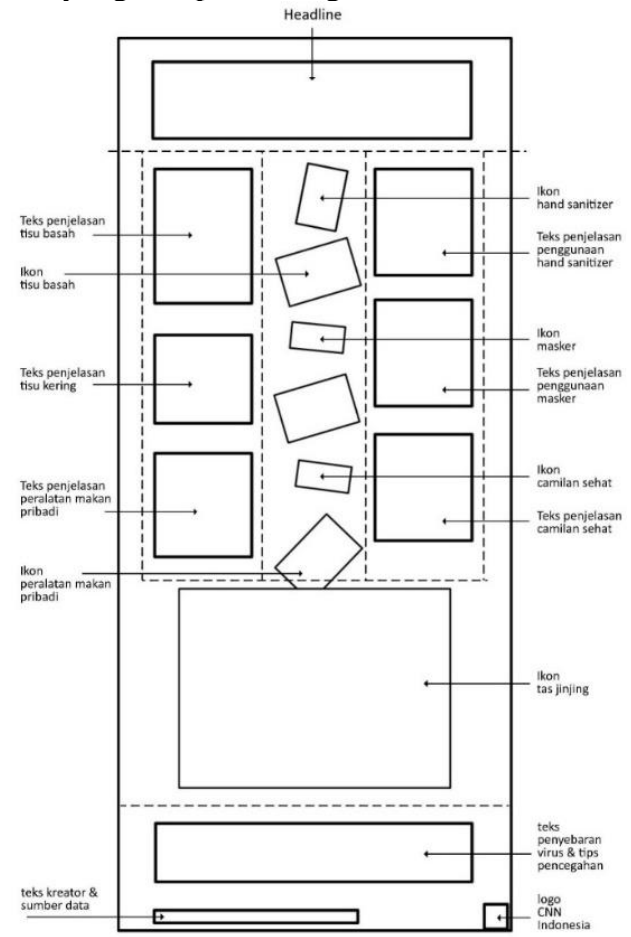

Gambar 8. layout infografis CNN Indonesia

"Yang harus ada di tas untuk mencegah Corona"

Sumber: penyederhanaan peneliti dari gambar 9

\section{Indeks infografis CNN Indonesia}

Secara visual, infografis ini hanya menggunakan 4 palet warna (oranye, merah tua, putih, hitam) sehingga dapat meningkatkan fokus pembaca pada informasi yang disampaikan. Pemilihan objek tas model jinjing selempang yang biasa digunakan sebagai tas untuk kebutuhan sekolah, ke kampus dan bekerja menunjukkan bahwa infografis ini lebih ditujukan kepada orang-orang yang masih aktif melakukan kegiatan di luar rumah. Hal tersebut sejalan dengan pemilihan warna oranye yang dominan pada background di mana menyiratkan suasana penuh energi, kreatif dan semangat beraktifitas. Makna warna di sini seolah mengajak pembaca dalam masa aktif berkegiatan untuk tetap waspada melalui penyediaan beberapa barang sebagai bentuk pencegahan virus Corona. Pemilihan warna yang cerah dengan 4 palet warna menunjukkan konsep minimalis, menyampaikan hanya elemen-elemen yang memang penting mewakili data dengan cara jelas dan efisien.

\section{Simbol infografis CNN Indonesia}

Teks headline yang berbunyi "Yang harus ada di tas untuk mencegah Corona" adalah kalimat persuasif. Pembukaan tersebut cukup efektif karena mengandung kalimat "Yang harus ada di tas..." di mana pembaca diarahkan kepada penyebutan benda atau produk fisik. Typeface yang digunakan adalah jenis San Serif, huruf tidak memiliki kaki, bertangkai tebal, sederhana serta tingkat keterbacaannya tinggi.
Teks headline, subheadline dan closing menggunakan huruf kapital sehingga memberi kesan penting dan lebih formal, sedangkan teks penjelasan item-item pencegah virus Corona menggunakan huruf kecil dengan mempertahankan ketebalan, terkesan lebih kasual dan kokoh. Kesan dari font secara keseluruhan menggambarkan kesan kokoh, modern tetapi informal. Teks gelap di atas background terang menunjukkan desain infografis tersebut memperhatikan sisi kontras untuk meningkatkan tingkat keterbacaan.

Infografis ini hanya menggunakan satu jenis typeface, hal ini yang sejalan dengan konsep minimalis dari infografis secara keseluruhan. Secara visual, peneliti menemukan hanya satu simbol gambar, yaitu tanda plus pada ikon hand sanitizer. Simbol tersebut dipahami secara konvensional sebagai lambang palang merah di Indonesia. Sebenarnya terdapat lambang lain terkait palang merah yang diakui di dunia seperti bulan sabit merah dan prisma merah. Maka, simbol berupa tanda plus atau palang tersebut tepat digunakan untuk target pembaca di Indonesia. Teks penutup berisi informasi singkat cara penyebaran virus Corona dan solusi cara mencegahnya. Bagian berikutnya adalah teks tentang kreator dan sumber data. Alur pembacaan infografis diakhiri dengan penyantuman logo CNN Indonesia di bagian kanan bawah.

\section{Kesimpulan analisis infografis CNN Indonesia}

Infografis "Novel Coronavirus" CNN Indonesia juga banyak memanfaatkan ikon dibandingkan simbol dalam penyampaian informasi. Pembaca pertama kali disambut dengan headline teks "Yang harus ada di tas untuk mencegah corona" yang sekaligus membantu titik fokus konten pada suatu objek. Selanjutnya pembaca diarahkan ke bodycopy yang terbagi menjadi tiga kolom. Kolom tengah berisi ikon, sedangkan kolom terluar terdiri dari teks penjelas yang terkait dengan ikon yang terkait. Ada keseimbangan simetris yang terbentuk karena adanya sederet gambar yang secara maya membentuk garis vertikal sebagai poros tengahnya.

Infografis tersebut mengusung konsep visual yang minimalis melalui elemen-elemen yang memang penting mewakili data secara jelas dan efisien, dengan kata lain penyampaian informasi lebih diutamakan. Namun, ini menjadi kontradiktif akibat penyantuman teks "berbagai sumber" sebagai sumber data primer. Hal tersebut menunjukkan kurangnya perhatian pada kredibilitas informasi karena terkesan luas dan generik. Sebagaimana diketahui secara umum bahwa alur pembacaan masyarakat Indonesia adalah dari kiri ke kanan dan atas ke bawah, teks bodycopy pada kolom tengah dapat memunculkan ambigu alur baca. Setelah pembaca mencerna teks penjelasan tentang tisu basah, pembaca cenderung akan melihat ikon hand sanitizer dahulu kemudian melihat ikon tisu basah. Hal tersebut juga terjadi pada ikon-ikon lainnya. Kekurangan tersebut dapat diminimalisir dengan kejelasan gambar ilustrasi. 
Kelebihan infografis ini adalah mengemban citra yang menyiratkan suasana penuh energi, kreatif, semangat beraktifitas, namun tetap waspada melalui penyediaan beberapa barang sebagai bentuk pencegahan virus Corona selama beraktifitas.

\section{Kajian kedua: infografis Kompas.com Ikon infografis Kompas.com}

Pembaca disambut dengan teks headline dan ikon virus Corona. Ikon tersebut digambarkan seperti Amuba, makhluk bersel satu, dengan duri dan tentakel yang tumbuh di tubuh terluar. Virus Corona divisualisasikan dengan teknik vektor, berwarna oranye dan digambarkan melalui outline garis dinamis. Ilustrasi diwujudkan melalui outline, tanpa warna isian, bertujuan supaya terlihat lebih sederhana dan pembaca tetap fokus pada teks headline. Kesan yang hadir dari visualisasi virus adalah kesan netral, tidak ada personifikasi virus sebagai monster yang mengancam. Ikon pasien pria paruh baya mengenakan syal rajut dan memakai baju lengan panjang mendominasi bagian tengah infografis. Ikon pasien tersebut berukuran lebih besar dari pada ikon-ikon lain di bagian tengah infografis, sehingga berhasil menjadi point of interest kedua setelah headline. Ikon pasien tersebut berada di dalam ruang berwarna putih dengan virus Corona berwarna biru sebagai latar belakang. Hal tersebut menggambarkan gejala klinis Covid-10 yang dialami pasien dilatar belakangi oleh virus Corona. Selanjutnya di kolom bagian pencegahan terdapat ikon cuci tangan, masker, wajah kucing, orang menutupi wajah dengan kertas tisu, potongan daging, piring berisi sayur mayur, dan terakhir wanita berolahraga. Pada bagian kolom bawah atau penutup, terdapat ikon dokter dengan atribut buku kerja, alat stetoskop dan mengenakan masker.

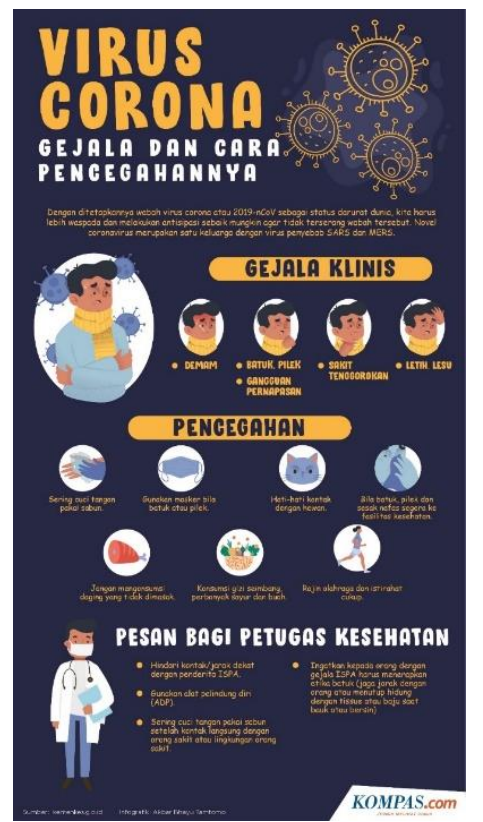

Gambar 9. infografis Kompas.com "virus Corona, gejala dan cara pencegahannya" Sumber: https://www.kompas.com/tren/ read/2020/02/11/173200765/ infografik-virus-corona-gejaladan-cara-pencegahannya

Diakses pada 20 Februari 2020

Pembaca mungkin sekilas menganggap dokter memberikan informasi berupa pesan kepada pasien yang tertuang pada teks di sebelah kanan, namun konten yang sebenarnya adalah pesan untuk petugas kesehatan. Ikon dan pesan verbal pada kolom bagian atas dan tengah infografis ditujukan kepada masyarakat luas, sedangkan ikon dan pesan verbal pada kolom bagian bawah lebih spesifik ditujukan pada petugas kesehatan dan orang-orang tertentu yang menjadi relawan tenaga medis penanganan Covid-19. Ikon-ikon dalam infografis ini divisualisasikan dengan gaya desain yang selaras dengan konsep jenaka dengan kesan netral secara keseluruhan.

Gambar di bawah ini merupakan layout penyederhanaan untuk memetakan tanda verbal dan visual yang ada pada infografis dari Kompas.com.

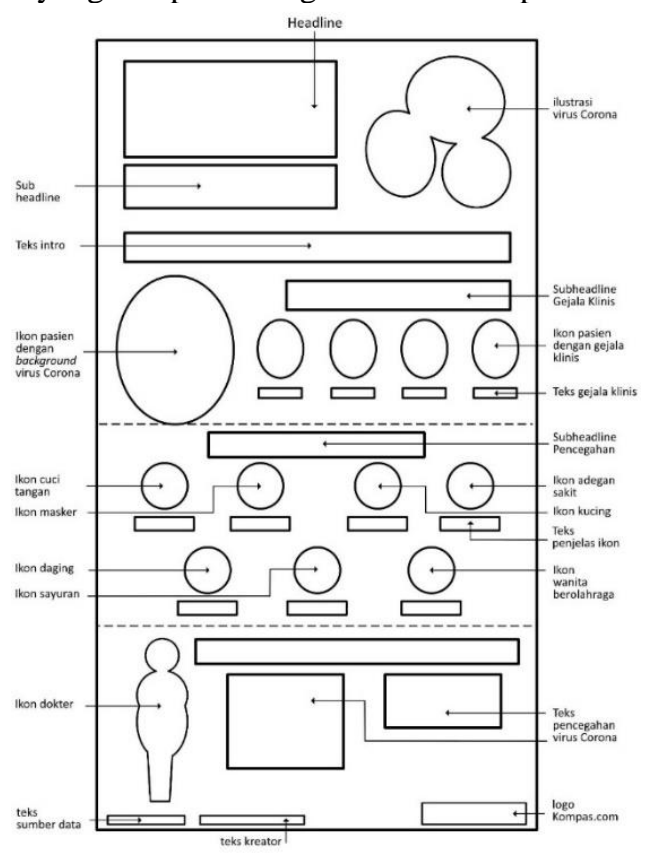

Gambar 10. Layout infografis Kompas.com "virus Corona, gejala dan cara pencegahannya" Sumber: penyederhanaan peneliti dari gambar 11

\section{Indeks infografis Kompas.com}

Secara visual, infografis dari Kompas.com tersebut menggunakan 4-5 palet warna yang dapat mengantarkan tingkat fokus yang cukup baik kepada pembaca. Warna biru tua memegang peran dominan sebagai background. Warna gelap tersebut memang menyiratkan kondisi yang suram apabila berdiri sendiri. Namun, kombinasi warna biru tua dengan oranye justru menciptakan kontras yang membuat elemen visual di dalamnya terlihat menonjol dan seolah mengajak pembaca untuk lebih fokus pada upaya pencegahan virus daripada tenggelam pada berita duka pasien Covid-19.

\section{Simbol infografis Kompas.com}


Teks headline yang berbunyi "Virus Corona, gejala dan cara pencegahannya" dan subheadline merupakan kalimat eksposisi, cenderung memaparkan informasi dan definisi terkait virus Corona. Sedangkan teks pada kolom bagian bawah atau penutup berupa pesan-pesan untuk petugas kesehatan merupakan kalimat persuasi. Teks headline dan subheadline menggunakan huruf kapital sehingga memberi kesan penting, sedangkan teks pencegahan virus Corona dan pesan untuk petugas kesehatan menggunakan huruf kecil dengan tetap mempertahankan ketebalan, terkesan lebih kasual.

Typeface untuk headline dan subheadline adalah jenis San Serif dengan corak kartun, huruf tidak memiliki kaki, terkesan sederhana serta namun tingkat keterbacaannya sedang. Sedangkan bodycopy pada teks penjelas menggunakan font Comic Sans tanpa ketebalan. Kesan dari font secara keseluruhan menggambarkan kesan jenaka, kasual dan informal. Infografis ini menggunakan dua jenis typeface dengan corak kartun. Hal ini yang sejalan dengan konsep jenaka dan kasual secara keseluruhan. Teks terang di atas background gelap atau sering disebut sebagai mode gelap (dark mode) pada perangkat smartphone menunjukkan bahwa desain infografis ini lebih mengedepankan tingkat kenyamanan pembaca dalam mencermati infografis dan terkesan elegan. Dalam konteks lain, mode gelap sering digunakan pula dalam aplikasi perangkat lunak untuk mengurangi ketegangan mata.

\section{Kesimpulan analisis infografis Kompas.com}

Infografis "Virus Corona, gejala dan cara pencegahannya" dari Kompas.com banyak memanfaatkan ikon dibandingkan simbol dalam penyampaian informasi. Dari sudut komposisi, pengelompokan infografis ini dibagi menjadi 3 ruang besar, yaitu bagian atas, tengah dan bawah dengan pembacaan alur yang sederhana (atas ke bawah, kiri ke kanan) sehingga mudah dipahami pembaca. Ada keseimbangan asimetris yang terbentuk dengan adanya susunan elemen berwarna oranye yang secara maya membentuk alur zig zag dari atas ke bawah. Secara visual, infografis ini mengusung konsep jenaka, kasual dan informal. Kombinasi warna dominan biru tua dengan elemen berwarna oranye menciptakan kontras yang membuat elemen visual di dalamnya terlihat menonjol, seolah mengajak pembaca untuk lebih fokus pada upaya pencegahan virus daripada tenggelam pada berita duka pasien Covid-19.

\section{Kajian ketiga: infografis Kumparan.com Ikon infografis Kumparan.com}

Ikon yang menjadi point of interest adalah infografis ini adalah ikon dokter yang terletak di kolom bagian kiri. Apabila ikon tersebut berdiri sendiri, pembaca mungkin tidak mengidentifikasi gambar tersebut sebagai dokter. Hal ini disebabkan karena pakaian dan atribut yang ada pada ilustrasi tersebut belum secara penuh menggambarkan citra dokter, seperti adanya masker, alat Stetoskop, atau atribut lainnya. Namun, kekurangan tersebut dapat diminimalisir dengan kehadiran konteks "virus Corona" melalui headline dan ikon-ikon di bawahnya, sehingga pembaca dapat menyimpulkan ikon tersebut sebagai dokter yang menyampaikan definisi virus Corona melalui balon kata di sebelah kanan karakter.

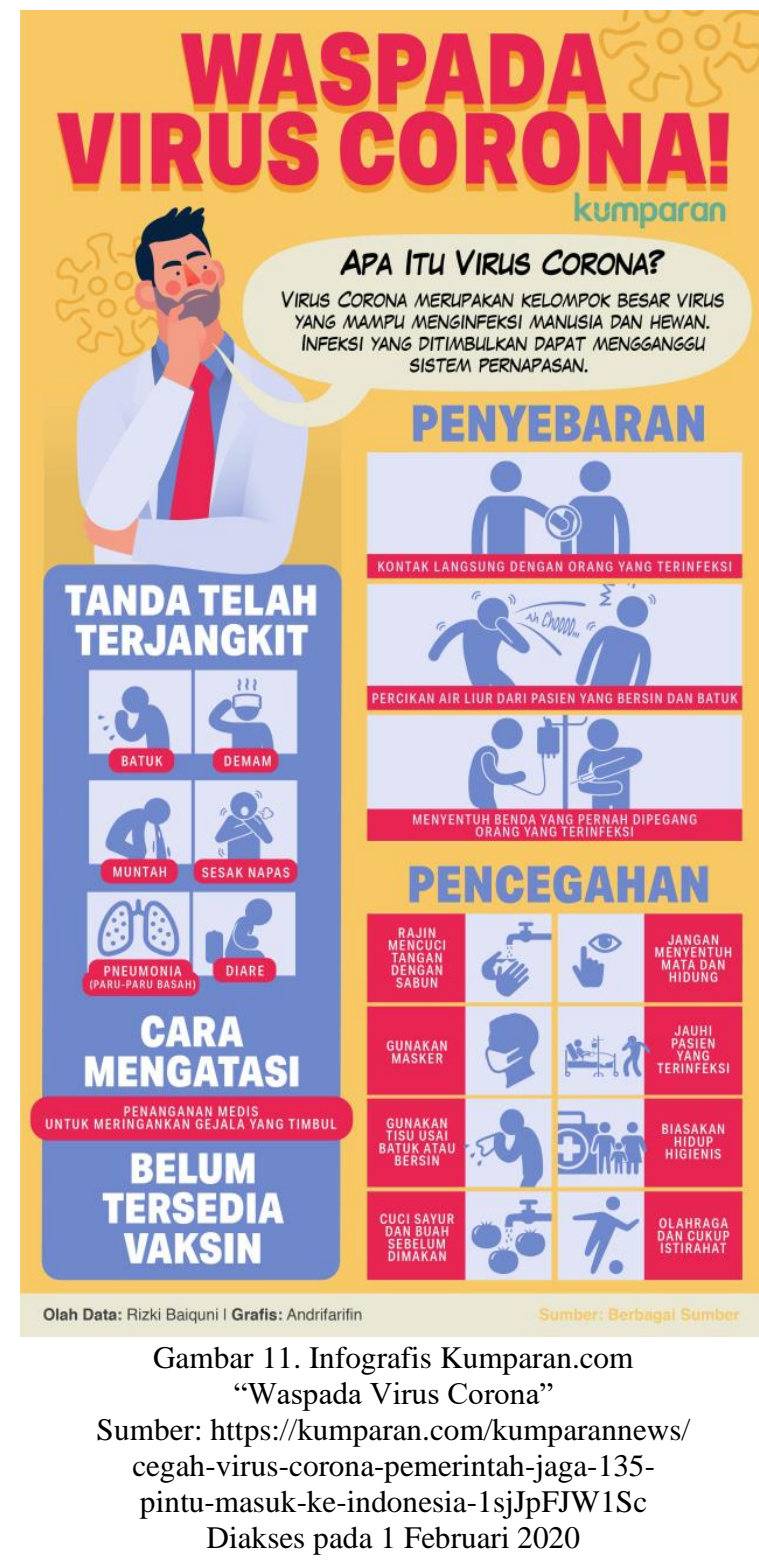

Pembaca kemudian diarahkan ke kolom biru sebelah kiri dengan judul 'Tanda telah terjangkit' dan kolom merah di sebelah kanan dengan judul 'Penyebaran' dan 'Pencegahan'. Ikon-ikon di dalam kolom tersebut diwujudkan dengan gaya komik kartun (cartoon style). Karakter siluet berwarna biru masingmasing menggambarkan gejala klinis tanda terjangkit, cara penyebaran hingga bentuk pencegahan yang mudah dipahami. Namun, terdapat ikon yang kurang mengindahkan prinsip continuity, yaitu pada ikon orang batuk yang menghadap ke kiri. Komposisi 
tersebut justru akan mengarahkan pembaca keluar dari alur baca.

Gambar di bawah ini merupakan layout penyederhanaan untuk memetakan tanda verbal dan visual yang ada pada infografis dari Kumparan.com

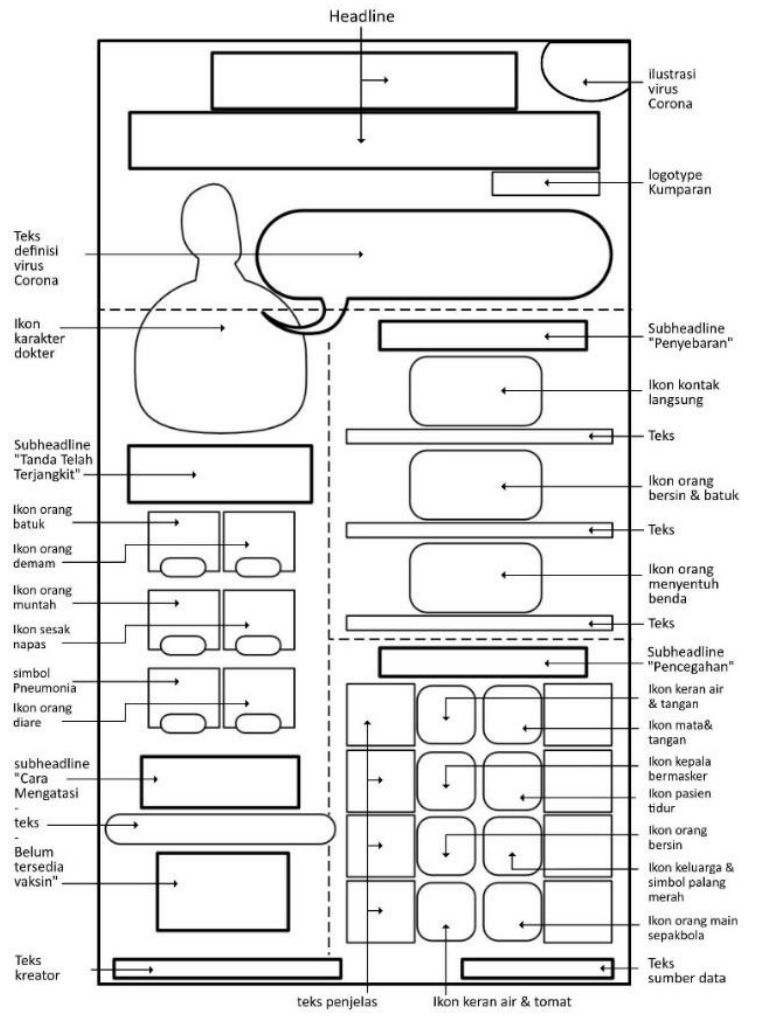

Gambar 12. Layout infografis Kumparan.com "Waspada Virus Corona"

Sumber: penyederhanaan peneliti dari gambar 13

\section{Indeks infografis Kumparan.com}

Warna merah pada headline "Waspada Virus Corona!" secara verbal mendorong pembaca untuk berhati-hati pada virus Corona. Hal tersebut selaras dengan tampilan visual teks dengan typeface Sans Serif yang berkarakter tebal dan bernuansa kokoh. Selanjutnya, pembaca diarahkan pada ikon dokter yang mengucapkan teks berisi definisi virus Corona. Sayangnya, pakaian dan atribut yang ada pada ilustrasi tersebut belum secara penuh menggambarkan citra dokter. Alat Stetoskop yang biasa dikalungkan di leher dokter tidak ditemukan pada ilutrasi tersebut. Kemudian pada kolom biru sebelah kiri, ikon-ikon dalam panel kolom 'Tanda telah terjangkit' digambarkan dengan baik dan efisien beserta elemen visual yang termasuk dalam tanda indeks. Indeksindeks tersebut membantu pembaca untuk memahami bahasa tubuh tokoh, seperti semburan air liur pada orang batuk, garis dinamis di atas orang demam yang menunjukkan kesan panas, orang yang memuntahkan makanan, bentuk balon udara pada orang sesak napas, bintik-bintik di atas paru-paru yang menunjukkan paruparu basah, dan orang duduk di wastafel yang menunjukkan sedang menderita diare. Pola serupa juga berhasil diterapkan pada kolom di ruang sebelah kanan yang terdiri dari subheadline 'Penyebaran' dan 'Pencegahan'.

\section{Simbol infografis Kumparan.com}

Pembaca pertama kali disambut dengan teks headline "Waspada Virus Corona!" dengan teks berwarna merah dengan typeface Sans Serif. Kalimat tersebut diawali dengan kata "waspada" dan diakhiri dengan tanda seru (!) sehingga termasuk kalimat imperatif transitif. Selanjutnya, pembaca diarahkan pada balon kata yang diucapkan oleh dokter. Teks tersebut bersifat eksposisi dan divisualisasikan melalui typeface Script dengan nama font Komika Hand jenis regular. Citra dari teks balon kata tersebut selaras dengan gaya komik strip yang diusung. Namun, penggunaan typeface berganti setelah pembaca masuk ke subheadline lainnya, yaitu 'Tanda telah terjangkit', 'Cara mengatasi - belum tersedia vaksin', 'Penyebaran', dan 'Pencegahan'.

Pemilihan warna dengan dominan biru di kolom kiri, warna dominan merah di kolom kanan dengan variasi pada panel teks di dalamnya menciptakan keseimbangan asimetris, walaupun secara komposisi keseluruhan kolom bagian kanan masih terasa lebih berat atau lebih padat. Kombinasi warna biru-merah di atas background oranye menciptakan komposisi warna yang kontras dan menarik perhatian pembaca. Warna merah pada kolom 'Penyebaran' dan 'Pencegahan' dapat dimaknai sebagai hal yang secara agresif lebih penting untuk diperhatikan, dengan kata lain lebih baik mencegah daripada terjangkit penyakit. Sedangkan warna biru pada kolom 'Tanda telah terjangkit' dalam konteks gejala klinis dapat dimaknai sebagai hal persuasif untuk tetap tenang walau telah mendapatkan beberapa gejala klinis dan segera menjalani pengobatan.

\section{Kesimpulan analisis infografis Kumparan.com}

Infografis "Waspada Virus Corona" dari Kumparan.com memanfaatkan gaya komik strip dalam menampilkan ikon. Ilustrasi pada ikon-ikon dibentuk dari siluet orang-orang yang memperagakan suatu hal. Kelebihan infografis ini adalah mengemban citra yang menyiratkan suasana kreatif, namun tetap waspada melalui delapan ikon gambar berisi pencegahan virus Corona. Secara visual, ada konsistensi gaya visual dan jenis font yang dipilih, misalnya warna merah pada headline bermakna kewaspadaan selaras dengan tampilan visual teks dengan typeface Sans Serif berkarakter tebal dan bernuansa kokoh. Kelemahan infografis ini adalah kurang memperhatikan penyantuman sumber data secara jelas, baik secara visual dan verbal. Pemilihan warna sumber data yang kurang kontras membuatnya sekilas tidak terbaca, sedangkan kalimat "berbagai sumber" menunjukkan kurangnya kredibilitas nya sebagai sumber primer.

\section{Kajian keempat: infografis Indonesiabaik.id}




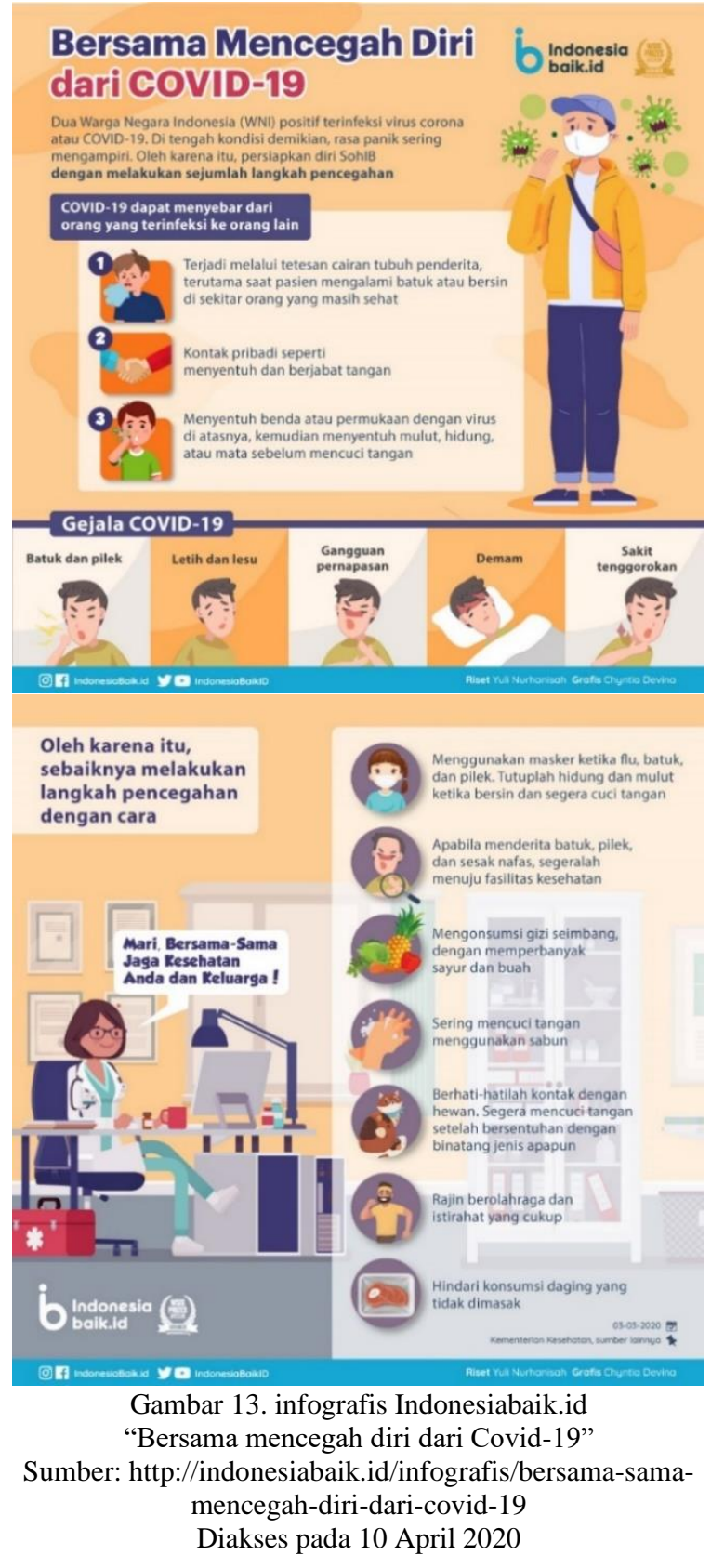

\section{Ikon infografis Indonesiabaik.id}

Ikon yang menarik perhatian pada slide pertama adalah ikon remaja berjaket warna oranye, bertopi biru, bercelana jeans, membawa sling bag, dan mengenakan masker putih. Ikon tersebut cukup berhasil menarik perhatian secara visual dan secara konteks yang mewakili target audiens, yaitu generasi milenial dan generasi Z. Virus Corona dipersonifikasikan dengan visualisasi monster berbentuk bola berwarna hijau sebesar telapak tangan manusia yang melayang di sekitar karakter manusia. Hal tersebut dapat dimaknai sebagai pesatnya penyebaran virus Corona yang dapat menyerang manusia, terutama bagi mereka yang tidak mengenakan alat pelindung seperti masker dan mengabaikan proses penyebaran virus.
Gambar di bawah ini merupakan layout penyederhanaan untuk memetakan tanda verbal dan visual yang ada pada infografis dari Indonesiabaik.id.

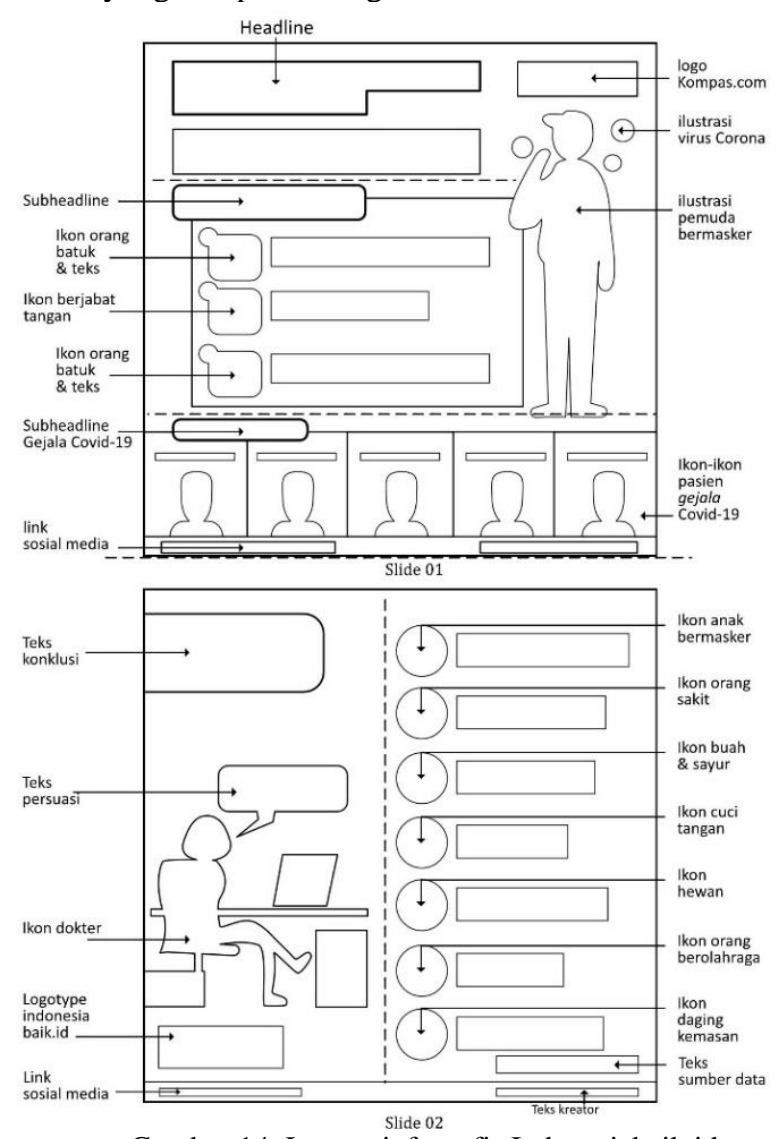

Gambar 14. Layout infografis Indonesiabaik.id "Bersama mencegah diri dari Covid-19"

Sumber: penyederhanaan peneliti dari gambar 17

Ikon yang cukup menarik perhatian terdapat pada slide kedua, yaitu ikon dokter atau tenaga medis perempuan. Ikon tersebut mewakili dokter melalui pakaian dan atribut yang menggambarkan citra dokter atau tenaga medis, seperti adanya masker, alat Stetoskop dan atribut lainnya. Keterkaitan antara slide pertama dengan slide kedua adalah kesamaan konteks dan hubungan sebab-akibat. Konteks yang melatarbelakangi adalah upaya mencegah virus Corona. Ikon-ikon yang dihadirkan dalam slide pertama dapat dimaknai sebagai teks-teks yang bersifat eksposisi, sedangkan ikon-ikon yang dihadirkan dalam slide kedua lebih bersifat persuasif. Perbedaan sifat antara kedua slide justru menciptakan hubungan sebabakibat, berupa penjelasan yang bersifat eksposisi dan ajakan untuk mencegah penyebaran virus melalui teks yang persuasif.

\section{Indeks infografis Indonesiabaik.id}

Secara visual, infografis ini menggunakan lebih dari 5 palet warna, namun lebih dominan warna oranye. sehingga dapat meningkatkan fokus pembaca pada informasi yang disampaikan. Ikon remaja berjaket warna oranye, bertopi biru, bercelana jeans, membawa sling bag, dan mengenakan masker putih dapat 
dimaknai sebagai perwakilan target audiens dari kalangan generasi milenial. Komposisi slide pertama dibagi 3 bagian, atas, tengah dan bawah. Ketiga bagian tersebut terhubung dengan prinsip continuity dalam konteks penyampaian pesan. Bagian atas menjelaskan tentang kondisi saat itu, bagian tengah menjelaskan tentang cara penyebaran, dan bagian bawah memaparkan kondisi orang dengan gejala klinis menderita Covid-19. Prinsip continuity diterapkan pada slide kedua melalui kalimat "oleh karena itu.." disusul dengan tujuh ikon dan penjelasan cara mencegah Covid-19.

\section{Simbol infografis Indonesiabaik.id}

Teks headline yang berbunyi "Bersama mencegah diri dari Covid-19" adalah kalimat persuasif. Pembukaan tersebut cukup efektif karena mengandung kalimat "Bersama mencegah..." di mana pembaca diajak dalam menerapkan langkah-langkah yang disampaikan. Teks headline "Bersama mencegah diri" berwarna biru ber-outline putih dapat dimaknai sebagai ajakan yang dapat dipertanggung jawabkan, diyakini dan dipercaya. Sedangkan teks headline "dari Covid19" berwarna merah ber-outline putih dapat dimaknai sebagai pengingat tentang sesuatu yang berbahaya.

Typeface yang digunakan adalah jenis San Serif, huruf tidak memiliki kaki, bertangkai tebal, sederhana serta tingkat keterbacaannya tinggi. Teks headline, subheadline dan closing menggunakan huruf kecil (dengan kapital hanya di awal kata) dan berkarakter tebal sehingga memberi kesan informal namun penting, sedangkan teks penjelasan item-item pencegah virus Corona menggunakan huruf kecil dengan karakter reguler, terkesan lebih kasual.

Kesan dari font secara keseluruhan menggambarkan citra modern, informal, namun kurang dinamis. Teks gelap di atas background terang menunjukkan desain infografis tersebut lebih memperhatikan tingkat keterbacaan. Infografis ini hanya menggunakan satu jenis typeface dengan dua macam font. Dalam hal ini, konsep teks tersebut kurang sesuai dengan kesan infografis secara keseluruhan yang terlihat dinamis dan jenaka.

\section{Kesimpulan analisis infografis Indonesiabaik.id}

Secara keseluruhan infografis ini menyiratkan suasana kreatif dan optimis dalam mencegah Covid-19, berhasil menunjukkan perhatian pada kredibilitas sumber informasi melalui penyantuman sumber spesifik dan waktu pembuatan infografis. Dilema visual dalam infografis ini adalah penggunaan font dengan typeface Sans Serif. Tingkat keterbacaannya memang tinggi, namun font tersebut terkesan formal dan berseberangan dengan gaya desain yang diusung. Gaya visual, desain tokoh dan virus Corona yang digambarkan sebagai monster berwarna hijau, serta gaya verbal yang persuasif cukup menarik perhatian bagi generasi milennial dan generasi $\mathrm{Z}$.
Kajian kelima: infografis Katadata.co.id
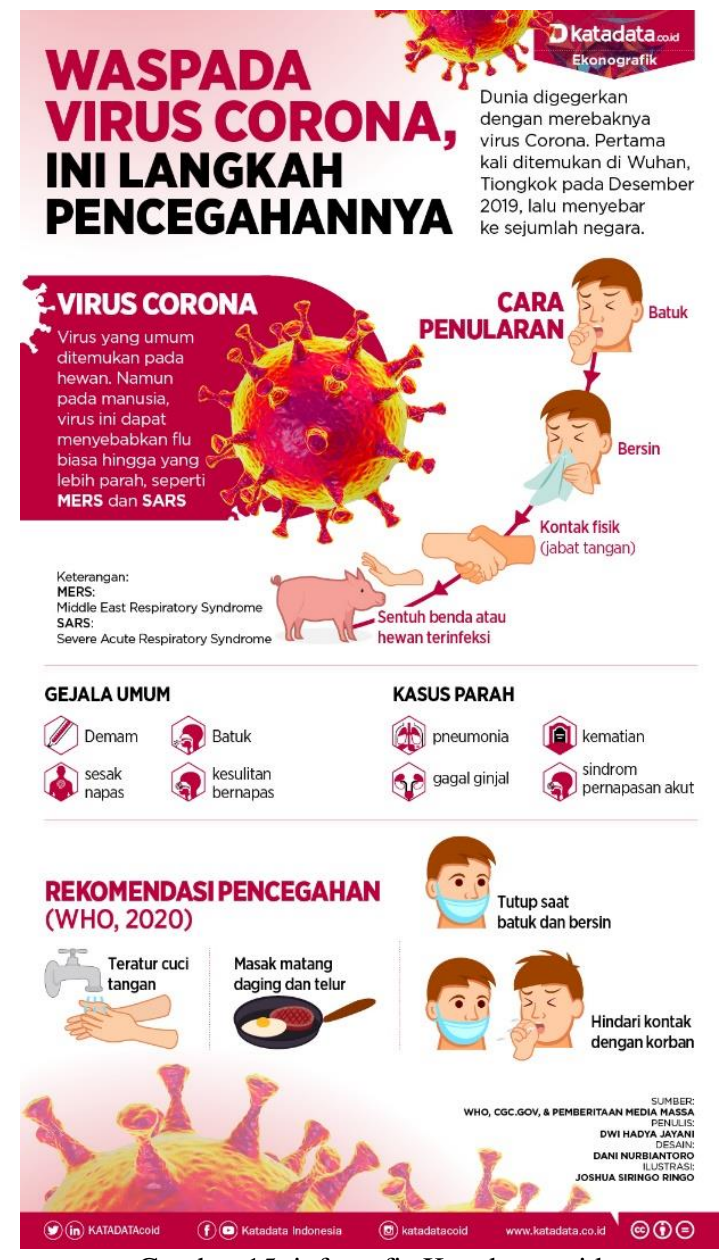

Gambar 15. infografis Katadata.co.id

"Waspada Virus Corona, ini langkah pencegahannya" Sumber: katadata.co.id/infografik/2020/01/24/

waspada-virus-corona-ini-langkah-pencegahannya Diakses pada 20 Februari 2020

\section{Ikon infografis Katadata.co.id}

Ikon virus Corona diilustrasikan dengan teknik tiga dimensi hyper realis, berwarna merah marun menyala dengan cahaya backlight berwarna tepi oranye. Ikon tersebut memang tidak dipersonifikasikan sebagai monster yang memiliki wajah, namun melalui perwujudan yang realis tersebut memberikan citra serius sebagai objek yang hadir di kehidupan nyata. Teknis visualisasi hyper realis diterapkan pada ikon virus Corona, sedangkan ikon-ikon pada bagian cara penularan, gejala umum, kasus parah, dan langkah pencegahan disajikan melalui gaya desain flat dengan teknik vektor. Gambar di bawah ini merupakan layout penyederhanaan untuk memetakan tanda verbal dan visual yang ada pada infografis dari Katadata.id. 


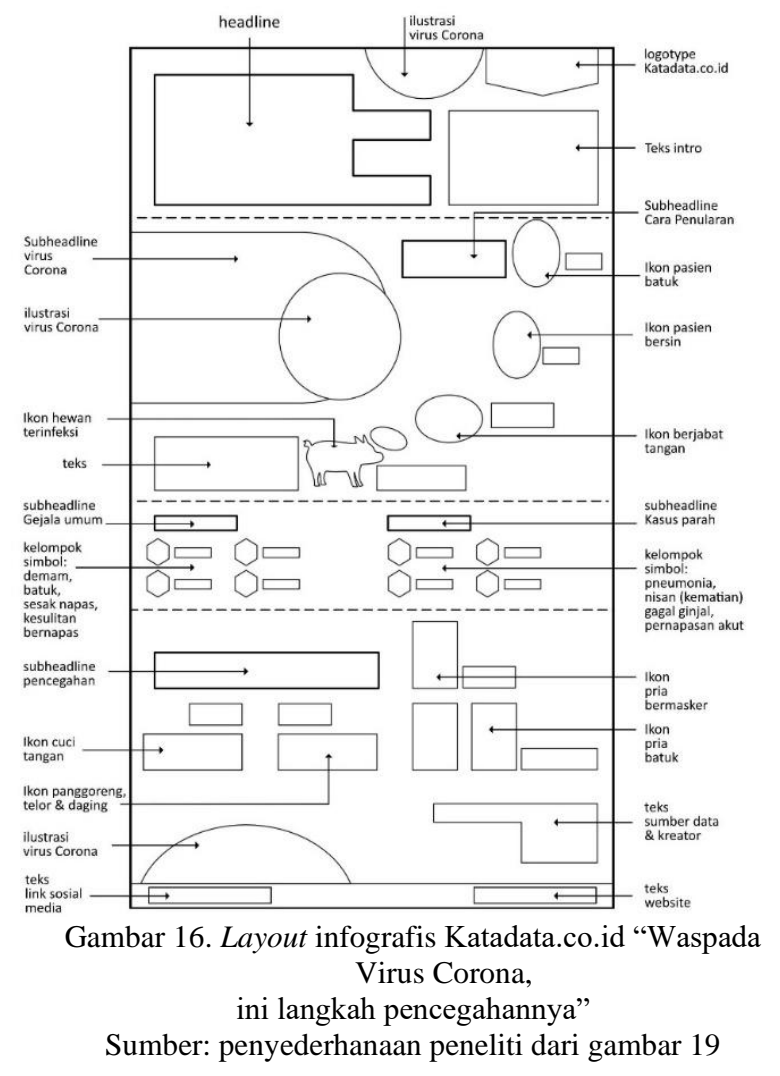

Indeks infografis Katadata.co.id

Komposisi infografis ini cenderung seimbang secara asimetri dengan tiga bagian besar (atas, tengah dan bawah). Warna yang paling mendominasi dalam infografis ini adalah warna putih yang diterapkan pada background. Warna mendominasi kedua adalah warna merah marun yang diterapkan pada panel, teks headline \& subheadline, dan ikon-ikon. Komposisi warna tersebut dapat dimaknai sebagai bentuk ajakan untuk tetap menjaga kesehatan, kebersihan dan tingkat steril (warna putih) di atas penyebaran virus Corona yang berbahaya dan harus diwaspadai (warna merah marun). Pada bagian atas infografis, terdapat alur cara penularan virus Corona dengan urutan ikon batuk, bersin, kontak fisik dan diakhiri dengan ikon menyentuh benda atau hewan yang terinfeksi. Sebenarnya urutan tersebut dapat membuat ambigu pembaca Indonesia karena terbiasa dengan alur baca kiri ke kanan, namun garis alur berwarna merah di belakang ikon-ikon 'cara penularan' dapat mengoreksi alur baca.

\section{Simbol infografis Katadata.co.id}

Teks headline yang berbunyi "Waspada virus Corona, ini langkah pencegahannya" adalah kalimat eksposisi. Pembukaan tersebut efektif dengan kalimat "Ini langkah pencegahannya..." di mana pembaca diarahkan kepada penyebutan langkah-langkah. Typeface yang digunakan adalah jenis San Serif, huruf tidak memiliki kaki, bertangkai tebal, terkesan sederhana namun tingkat keterbacaannya tinggi. Teks headline dan subheadline menggunakan huruf kapital sehingga memberi kesan penting dan lebih formal, sedangkan teks penjelasan item-item pencegah virus Corona menggunakan huruf kecil dengan karakter reguler, terkesan lebih kasual dan kokoh. Font secara keseluruhan menggambarkan kesan kokoh, modern dan formal.

\section{Kesimpulan analisis infografis Katadata.co.id}

Infografis ini menyiratkan kesan minimalis dengan penggunaan 4-5 warna saja, sehingga dapat meningkatkan tingkat point of interest dengan komposisnya yang cenderung seimbang. Walau pun secara visual menghadirkan komposisi yang padat, namun secara tekstual berhasil menunjukkan perhatian pada kredibilitas sumber informasi melalui penyantuman sumber spesifik. Pemilihan font dengan typeface Sans Serif memiliki tingkat keterbacaan tinggi dan memiliki kesan formal. Hal ini selaras dengan gaya desain yang diusung. Kesan minimalis, gaya desain flat pada ikon manusia, gaya desain hiper realis pada ikon virus Corona, dan gaya verbal eksposisi secara keseluruhan masih menarik perhatian bagi generasi $\mathrm{X}$ dan generasi milennial. Secara visual, infografis ini mengusung konsep minimalis, warna putih yang dominan sebagai background memberi kesan whitespace yang luas. Penyantuman teks "WHO, CGV \& Pemberitaan Media Massa" sebagai sumber data primer cukup meningkatkan kredibilitas infografis.

\section{PENUTUP}

Sistem tanda dalam beberapa infografis dengan tema 'Pencegahan Covid-19' yang dikaji terdiri dari tanda verbal dan tanda visual. Tanda yang terkadung memberikan makna melalui kode sesuai dengan sosial budaya target pembaca. Elemen visual dan verbal diklasifikasikan menjadi tiga jenis tanda yaitu ikon, indeks, dan simbol (pendekatan semiotika Peirce).

Peneliti mendapatkan beberapa kesimpulan berdasarkan persamaan ide besar dan beberapa perbedaan terkait prinsip desain analitik serta alur penyampaian pesan. Melalui angket sepuluh pertanyaan dengan cara SUS, peneliti memperoleh skor-skor yang dapat diterjemahkan dengan penilaian grade dan adjective rating. Hasil skor SUS terkait infografis pencegahan virus Corona antara lain, infografis yang dibuat oleh CNNIndonesia.com berada dalam grade $\mathrm{B}$ dan masuk rating Good. Sedangkan infografis lainnya seperti Kompas.com, Kumparan, Indonesiabaik.id, dan Katadata.co.id masuk dalam grade $\mathrm{A}$, dengan kata lain masuk dalam rating Excellent. Skor SUS Final tertinggi dipegang oleh Indonesiabaik.id sebanyak 84,8 poin.

Kelima infografis tersebut memperhatikan prinsip hubungan sebab-akibat (causality), persuasi, keterbacaan, dan komprehensif. Kekurangan yang cukup jelas adalah pada penerapan prinsip kredibilitas (credibility). Dua dari lima sampel infografis kurang memperhatikan kredibilitas karena tidak menyantumkan teks sumber data primer secara spesifik. Teks di dalam infografis pencegahan virus 
Corona merupakan bentuk komunikasi verbal dalam menyampaikan nilai edukasi dan unsur persuasi. Alur logika yang dibangun antara lain: menyebutkan pengertian virus Corona, cara penyebarannya, gejala klinik penderita Covid-19, cara mencegah penyebaran, dan sumber data serta nomer kontak yang bisa dihubungi pembaca untuk info lebih dalam.

Perbedaan-perbedaan terdapat pada konsep visual dalam sampel infografis. Citra yang tersirat dari desain infografis tersebut antara lain kesan modern, kasual, informal, dan jenaka/ komikal. Perbedaan lain terkait perhatian pada kredibilitas sumber data primer. Infografis yang dibuat oleh Indonesiabaik.id mempersonifikasi virus Corona dengan gaya kartun sebagai makhluk berbentuk bola berduri berwarna hijau yang umum dilihat sebagai kuman di media iklan Indonesia. Sedangkan Katadata.co.id memvisualisasi virus Corona dengan gaya hyper realis sebagai objek bola berwarna merah dan memiliki tentakel pendek.

Pendekatan yang digunakan kelima sampel infografis secara garis besar adalah naratif eksploratif sebagaimana struktur infografis pada umumnya yang memadukan bahasa verbal dan bahasa visual. Melalui proses kajian ini, peneliti memberikan saran kepada tim penyusun dan desainer infografis terutama dari media massa Indonesia, untuk selalu menyebutkan sumber primer secara spesifik sebagai wujud perhatian kepada prinsip kredibilitas. Infografis memang harus didesain dengan menarik secara artistik, namun juga akan lebih baik apabila mampu berdampak persuasif kepada pembaca.

\section{DAFTAR PUSTAKA}

Bahari, N. (2017). Kritik Seni. Pustaka Pelajar.

Benoit, G. (2019). Introduction to Information
Visualization. Rowman \& Littlefield.

Brooke, J. (1996). SUS - A quick and dirty usability scale. In P. W. Jordan, B. Thomas, B. A. Weerdmeester, \& I. L. McClelland, Usability Evaluation in Industry. Taylor \& Francis Ltd.

Fiske, J. (2002). Introduction to communication studies. Taylor \& Francis e-Library.

Lankow, J. (2014). Infografis: Kedahsyatan Cara Bercerita Visual. Terjemahan Alex Tri. PT Gramedia Pustaka Utama.

Liputan6.com. (2020, April 8). 4 Negara Ini Putuskan Tidak Lockdown karena Virus Corona. Retrieved from Liputan6.com: https://www.liputan6.com/global/read/4204231/4 -negara-ini-putuskan-tidak-lockdown-karenavirus-corona-seperti-indonesia

Piliang, Y. A. (2012). Semiotika dan Hipersemiotika: Gaya, Kode dan Matinya Makna. Pustaka Matahari.

Sobur, A. (2001). Analisis Teks Media: Suatu Pengantar Untuk Analisis Wacana, Analisis Semiotika dan Analisis Framing. Remaja Karya.

Tufte, E. R. (2006). Beautiful Evidence. Graphic Press LLC.

WHO. (2020, April 8). Coronavirus. Retrieved from World Health Organization: https://www.who.int/healthtopics/coronavirus\#tab=tab_1

Wilson, C. (2013). Credible Checklists and Quality Questionnaires: A User-Centered Design Method. Elsevier. 